\title{
Recognition of Traditional Games in Indonesia as Cultural Preservation Efforts Through Special Event
}

\author{
Yulia Lintangkawuryan \\ Sekolah Tinggi Pariwisata Trisakti \\ Jakarta, Indonesia \\ Yulialintang@stptrisakti.ac.id
}

\author{
Maria Pia Adiati \\ Hotel Management \\ Bina Nusantara University \\ Jakarta, Indonesia \\ Mia_pia_adiati@hotmail.com
}

\begin{abstract}
This research discusses the introduction to build the awareness and recognition of the traditional games in this country. The existence of these traditional games start to be erased along with the movement of the era. This threatened existence cause many children and youth, as the main actor in the preservation of national culture, even do not know about this treasure heritage. Based on that concern writers try to make an activity to introduce various kinds of traditional games from some parts of Indonesia that applicable and suitable enough with today's condition.. The benefits value of the games also being presented together with the tutorial. This thesis is formed in an outing activity with the traditional games as the tools. Nusantara game activities with the introduction of those aspects in which the value of culture, philosophy, history, role, application, and benefits should be part in preserving national culture and also provide for regional cultural traits. This study combine the methodology of R\&D and Action Research with descriptive approach with qualitative data approach. The results of this study identified that the game does have a big part in the archipelago nation's cultural heritage. Through the efforts of recognition given in the project, this activities carried out that the traditional games need to be introduced to the people as a cultural preservation efforts since by recognize these games and its aspects will enhance the awareness of individuals and groups about the importance of preserving the national culture in this form of traditional games.
\end{abstract}

Keywords - Traditional games, national heritage, preservation

\section{INTRODUCTION}

Indonesia is a country with multiple kinds of traditional games along the archipelago which has been the trait and the characteristics of the local culture. But the reality come with the worrying fact that the existence of these traditional games are already experiencing crushing increasingly widespread existence by modern games, which in essence is not rooted in local cultural identity that has been the legacy and the cultural treasures of the archipelago of ancestors or ancestral Indonesia. Kroeber (Dharmamulya, et al, 2008: 5) argues that if the ancestors of Indonesia does not have the passion to play, perhaps we will inherit the culture that lack of fineness will and poor of intellectuality.

Dharmamulya also mentioned that the game Archipelago contains some value that can be implanted. Those values include a sense of pleasure, a sense of freedom, a sense of friends, a sense of democracy, full of responsibility, a sense of abiding, mutual aid, all of which are values that are very good and useful in people's lives. Actually there are many reasons why the existence of children traditional games, that used to be the characteristic of some particular area, now beginning to disappear.

Games of archipelago nation is a cultural richness that has the noble values to be passed on to children as the next generation. Games o archipelago is a game that contains wisdom (Suseno, 1999). The game is also the archipelago nation's cultural wealth (Sedyawati, 1999). The study conducted by researchers that the game is one of the cultural heritage which should be preserved and become the nation's identity

In essence, the game is a part of human behavior, which is also a part of culture. Culture is a complex whole which includes knowledge, belief, art, morals, law, custom and any other capabilities and habits of humans as members of society. Many opinions that say that the game is a heritage, a legacy of the ancestors, so as to preserve the game, also preserve most cultural ancestry. But the inheritance itself is always changing according to the changing times and cultural development.

Nusantara game in this case is also called traditional games can be stated as a principle factor of cultural value is still there, alive, and can be preserved. Through traditional games that people can know and be able to learn about the natural history, science and culture.

Astuti research (2002) shows that traditional games can improve social skills. While research Masturi (in Markamah, 2007) showed that traditional games can improve the ability to empathize. Both of these studies reveal two aspects of emotional intelligence through traditional games.

Thus the loss or lack of a traditional game is played or presented in public life, the value and benefits available in the game will also be lost. It is necessary for the preservation of culture. This will be the discussion selected by authors for the research described in this time.

This research aims to develop an activity that is beneficial to introduce the culture of the archipelago through traditional games such as: Galasin, Gasing, Bentengan, Cublak - Cublak Suweng, and Congklak to the community as a cultural preservation efforts. 
This study will examine the effect from the introduction of the traditional game for the preservation of the cultural heritage of Indonesia. Questions that can be asked are as follows:

1. How the public interest is now on the domestic game?

2. What are the domestic game can still be done in today's modern lifestyle?

3. What is the philosophy that can be taken from these games?

4. How does the traditional games in Archipelago impact to the preservation of cultural heritage and cultural areas?

\section{LITERATURE REVIEW}

This chapter will describe some of the theories that relate to the discussion in the study. On the basis, the existing theory can be used as a guideline to determine the pace and solving problems that arise in this study. The basis of the theory that have relevance to this study are as follows:

\section{A. Folklore and Permainan Nusantara}

Foklore is part of the various collective culture in the world in general and in Indonesia in particular, the spread of hereditary among collectives concerned, either verbally, or are accompanied by gesture or auxiliaries reminders or mnemonic devices (Danandjaya, 1986). Folklore can be vernacular, traditional expressions, riddles, folklore, folk songs, folk games, folk theater, folk beliefs, folk architecture, folk music, and so on. Folk games are often also referred to as the traditional game.

Some research in some countries that tried to examine the traditional game refers to the indigenous research in the country and try to dig up and identify it. Krasilnikov (2006) conducted a study on the traditional game in Siberia society, Burnett \& Hollander (2004) conducted a research project to explore the traditional game in South Africa, and Ofele (2000) conducted a study and assessment of traditional games and associate it with learning in Argentina. From the results of these studies indicate that the traditional game or a game of the people has become part of the culture that has developed and taught for generations.

Research on archipelago games in Indonesia is still limited publicized. The author has conducted a series of research and study of traditional games in Indonesia in a sustainable manner, which identify traditional games (Iswinarti, 2005), analyzed in the review of the development of intellectual, social, emotional, and personality (National Symposium Psychology, Indonesia, 2005), and develop Guidelines for Gaming Traditional child (2007).

Bishop \& Curtis (2005) defines traditional games as games that have been passed down from one generation to the next. The game contains a good, positive, valuable, and desirable. There is a consensus that the traditional game refers to activities such as hopscotch (hopscotch), play marbles, jump rope, rubber games, and so on. But actually some games like practical jokes, initiations rituals, giving a nickname, and so also is the traditional game for the game has a long history and documented. Then Bishop \& Curtis (2005) classifies playing traditions into three groups, namely the conditions of the game with a cargo of verbal, game laden with imaginative, and the game is laden with the physical. As for the traditional games that will be the focus of this research is a traditional game that contains elements of rules and involve more than one person.

The traditional game is a term that is commonly used to refer to different types of games typical of a certain area, which has been played by the local people for generations.

Traditional game refer by PLSPO Depdikbud (1983) is a sport or a game that has long been available, which sometimes has nothing to do with traditional ceremonies or other activities that have to do with the struggle of life. Known also as sport, because usually that games involve physical activity and require (gross motor skills). Games like mentioned above are classified into something traditional because of certain activities constitute "ritual or habit" that are commonly done since the first, and usually better facilities and infrastructure needed to perform these activities in the form of objects that are old fashion and not yet touched by modernity. Haviland (1987) states that something can be called traditional or tradition when it is old habits (old cultural practices) which typically have characteristics that contrast with the current practice.

\section{Heritage And Traditional GAme}

Not long ago, we face a problem that is quite horrendous because Indonesia's traditional culture considered to have been stolen by one of the neighboring countries, such as Malaysia. Theft traditional culture such as: batik, angklung to folk songs incurs the wrath of the people of Indonesia.

But it also makes the problems of Indonesian society during these sides that turns traditional culture itself has been overlooked and missed so other nations who are smarter could use it for their benefit. Is the Indonesian society should be blamed because it has failed to protect their own national culture?

Actually not easy to answer that question. Because human life is never static and on over time will always experience social change including the culture according to Selo Soemardjan and Soelaeman Soemardi (1964) from the Faculty of Social-UI is a means of work, taste, and creative community. So inevitably we are going to change from the old culture into a new culture that may be partially or completely. Boyd and Timothy in his Heritage Tourism (2003) explains that "Heritage is selective, the historical record is incomplete and not all legacy is what society values. What you want to keep is the choice of the past. This screening process may be intentional or unintentional, but the people through a value system that no doubt changed from time to time "Society is formed through a long history, winding journey, for the sake of the tread footprint, trial and error. At certain points there are relics which exist or recorded until now which later became cultural heritage. Cultural heritage, according to Davidson (1991: 2) is defined as 'A product or result of physical culture from different traditions and spiritual achievements in the form of the value from the past are becoming essential element in the 
identity of a group or a nation'. So the cultural heritage is the result of physical culture (tangible) and cultural values (intangible) of the past. Cultural values of the past (intangible heritage) is derived from local cultures in the archipelago, include: tradition, folklore and legends, the mother tongue, oral history, creativity (dance, song, drama performances), adaptability and the uniqueness of the local community (Galla, 2001: 12).

If in ancient times cultural change usually occurs within a long and gradual, but in the modern era in the technological advances and globalization in every aspect of human life on this earth so that cultural change happens fairly quickly and often radical. No wonder if in Indonesia ensued cultural vertigo due to the intervention of modern culture.

In addition, our young generation as a product of modernism increasingly less interested in things that smelled of tradition because it is considered old-fashioned, outdated and belong only to the older generation alone. Faced with this situation, the government and all groups of people who care about this matter actually did not stay silent, because after traditional culture should be protected and preserved.

Moreover, if by Tashadi, researchers from Balai Kajian Sejarah dan Nilai Tradisional Yogyakarta that in traditional cultures contained noble values forming the national identity. When these values are lost and no longer understood by the younger generation so they will only have global values, and there goes the Indonesian national identity. The problem is the efforts of the maintenance and preservation of traditional culture today is not so easy to do in the middle of the rush of modern culture from the outside.

In addition to internal problems such as the lack of interest in the Indonesian people, especially the younger generation and preservation efforts that have not felt the repercussions, also external problems occur. Along with the development of the modern age is not the collective property of cultural products such as agrarian past but belongs individualist or ethnic group. Therefore, all cultural products, including contemporary and traditional arts were given the stamp belongs to an individual or group of people, even a nation.

When we fail to give people the stamp on the product's own culture, there was a cultural theft by other nations who later claimed to be the nation's cultural products. Therefore, according to Edi Sedyawati, there must be protection of cultural clearer then needed a special law for the protection of traditional cultural works. Indonesia's cultural diversity which consists of thousands of ethnic it must be patented to prevent theft by outside nations for its own sake.

In addition, although not easy cultural conservation efforts must remain intensively done in various ways including the performances of traditional cultural arts in various cultural centers or public place on an ongoing basis. The conservation effort will be a success if it is supported by various parties, including the government and the broad dissemination of mass media, including television. Then sooner or later, traditional culture back will be excited.

Traditional games also proved effective to develop social skills. During this time there were only from the point of measuring the development of intelligence and academic achievement of the school. But later proved that the field work skill level is not the measure of success from an individu, there are other significant developments maturity of emotional intelligence (Muslim, 2004). By playing, children can develop their creativity in ideas or lessons. With the development of creativity, children will be able to manifest itself, beneficial, rewarding and which enables are children can improve their quality of life. Research by Astuti (2002) showed that traditional games can improve social skills. While research Masturi (in Markamah, 2007) suggests that traditional games can increase the ability to empathize. Both of these studies reveal two aspects of emotional intelligence through traditional games.

The tendency of any nation or state, to preserve the tradition, including traditional game or sport has, is something that is universal. researching and studying games that are rooted in local communities, not solely for the benefit reconstruct history but furthermore would be very useful for the survival of human dignity.

The traditional game is the hallmark of a nation, and the results of a civilization. Which nations are not proud of their own culture? Therefore, explore, preserve and develop traditional sport is a matter that can not be avoided. Besides has become the hallmark of a nation, traditional sport is one of the major part of a broader framework that is culture.

In addition, traditional games, if arranged well, might be developed in order to attract the flow of tourists who are interested in the authenticity of the natural, regional specialties. Tourism will create activities and provide an opportunity for people to move, see, learn, socialize, get to know the culture, the environment, excellence, miracle or privileges elsewhere. Tourism will also evolve to travel to science and technology, tourism and culture.

\section{METHOD}

Methods focus on the strategy and approach in the process of doing research. This study uses research and development method (R \& D).

\section{RESULt}

The material searched through a search on the internet and library resources as well as using the networking of people who are experts in the field of culture, especially the game archipelago.

\section{A. Event Planning}

Once material and the experts are found, then the writers plan the event in details. The traditional games will be done as part of outing activity. Here is the detail of the event:

1. Venue : Saung Pawaka, Kampung Bojong Koneng, Sentul. The reason of choosing this venue because this venue has a wide field and suitable to held the games.

2. Day / Time : Thursday, $15^{\text {th }}$ May 2014. 
3. Packaging: The recognition of the traditional games will be done on outing activity. The outing participants will be demonstrated how to play specific traditional games and will be explained the value of each games.

4. Participant : a group of children and teenage from SMP Tarakanita III who will be model for this event and this group is under learning age.

5. The presenter of each games : a group of facilitator which has been briefed earlier.

6. The facilitator briefed three time on how to facilitate the games, how to explain the games and the value of the games.

7. Prepare the outing hands-out which explain the outing schedule and the material which will be demonstrated.

\section{B. Galasin or Gobak Sodor}

The term Gobag Sodor known in Central Java, whereas in other areas also called as Galah better known in Natuna Islands, while in some other areas like Riau Islands known as the Galah Panjang. Meanwhile in the mainland are, the game is also called Cak Bur or Main Belon. Being in the area of West Java, known by the name Galah Asin or Galasin. Galasin or Gobak Sodor is usually done in the field. Playground is a rectangular box and given a line in it. The game is usually played on the badminton court, by reference to existing lines or can be by using a rectangular field with a size of $9 \times 4 \mathrm{~m}$, divided into 6 sections. The boundary line of each section is usually marked with chalk. How to play are children divided into two teams, one team of 3-5 people. After determining which team guard, the game can begin. Members of the group who had a turn to keep the field is divided into two, namely members of the group who keep the boundary lines of horizontal and vertical boundary lines. For group members who have a duty to keep the horizontal boundary line, then they will try to hinder their opponents who are also trying to cross the boundary line that has been determined as the border freely. For group members who have a duty to maintain the vertical boundary line (usually only one person), then this person will have access to the entire vertical boundary lines are located in the middle of the field.

Teams that do not in charge just stand in line at the front and tried to break through the lines and did not break until touched by a team that case, as shown in Figure 5.2. After successfully break through the last line, they should be trying to get back to where they first started. If we had separated from our last boundary line becomes free spirit. This is where we are heading. If successful, they will get one value. Meanwhile, when there is a team member who touched mean a turn switch. Teams that touched will be on duty to guard. The winning team is that collects the most value. The benefits of this game is: Increase physical ability. Sharping the ability to read gestures / gesture. Improve communication skills and ability to strategize better.

\section{Gasing}

Gasing is a toy that can rotate on the shaft and balance at a point. Gasing is the oldest toy that was found in the archaeological sites and still recognizable. In addition to the toys of children and adults, also tops used for divination fate.
Words gasing have originated from the Malay language combination of two words, namely 'gah berpusing (berpusing = dizzy)'. Gah in terms of game gasing intends to spin (spin) quickly and straight.

Top is made of wood with a predetermined size, round shapes, so it has three important parts: head, body and stern gasing. At the bottom of the head gasing made little indentation (also known as a top neck) which serves as a rope wrapped around the top, because the top is rotated with a rope. At the stern was given axis to maintain balance when playing on the floor. Type of wood used to make the top include merbau (sympetalandra borneensis), Leban horn (vitex quinta), oranges, mangroves, kempas, Sepan (gymnopetalum cochinchinensis), keranji (cynoptera polyandra) mangosteen, guava, ciku (achras zapota) and tamarind wood. In addition, also tops made from plastic or other materials. Gasing played with five main steps, namely: Wrap tops with straps made of nylon or other material, a length of 3-5 m. The trick, first rope wrapped around his right hand, either on the arm or on the fingers. After that, the end of the rope is placed at the top of the neck, and then wound up part of a top agency covered by the windings. Spin gasing in a way pushed and pulled, or thrown then withdrawn. The first way, the position of the player body should be bent about 45 degrees and a top position should be upright and the position of the thumb should be facing upwards. When the top is removed, then the player's hand must be pulled with a little strength along spinning tops. Move gasing in a state of rotating to another place, aiming to ensure a durable rotation. Tackling gasing belong to the opponent. The last step is carried out at a top game, usually for tackle spinning gasing own by the opponent. The purpose and benefits of the game tops in the ancient times is not only a game but played a role as the rodents, the relationship between the local population. Gasing games to test skills, improve skills, hone skills in a group set strategy.

\section{Benteng /Bentengan/Pal-palan/Pris-prisan}

Bentengan game in some areas is often known as rerebonan in the area of western Java was in other areas are also known by the name pris-prisan, omer, jek-jekan.

The game consists of two groups or teams of players (Picture 5.7), the core of the game is who succeeded in occupying most opponents castle (with a touching symbol opponents castle). Each team will keep his castle fort (the form and the object is up, usually electricity poles, trees, walls, etc.) as well as attacking the opponents castle. Any attacker who already outpacing his castle, will be captured by guards, and if caught the attacker would be a prisoner. And had to be rescued by his friends to be able to play again. the successful group more occupy opponents castle, it was the one who wins the game.

The benefits of this game is to:

a. Train visual and motorik abilities.

b. Develop ability to read the motion or gesture

c. Improve concentration

d. Develop physical movement to run, which is beneficial for the body strength and skill in sports.

e. Exercise the control power of the eye. 


\section{f. Stimulate communication skills and strategize}

\section{E. Cublak - cublak Suweng}

Cublak-cublak suweng is a traditional game from Java that involves a lot of players. To make the game more exciting, there should be at least 3-5 people. Cublak-Cublak Suweng drawn from the goal of this game Pak Empo (people who have to guess) find earrings (Suweng) from hidden person. The game then begins by touching the gravel to every other participant palms (Figure 5.8). Throughout the game, the participants sing songs Cublak-Cublak Suweng. His poem, "Cublak-Cublak Suweng, suwenge teng-gelenter, mambu ketundung Gudel, pa empo lera lere, sopo ngguyu ndeliake". After coming to a word ndelikake, gravel must be held by a participant who last touched his hand. After the gravel grip, people have to guess get up and sit cross-legged. While other participants sang, "sir, sir pong ndelik gopong" as much as possible to the people who have to guess determine who hides the pebble. While singing, hand index shaken and directed to the person who has to guess. The man was only given one chance. If not successful, then he will be the one who had to guess on the next game. Being the one to guess, you should be careful not to fail guess for the second time. If it fails, the player is asked laps or ward where the play with a run squat. Sometimes players who fail are also asked to meet the unique demands of other players.

\section{F. Congklak}

Congklak is a game that is traditionally known by various names throughout Indonesia (Dhakon, Dentuman, Mokaotan, Maggaleceng, Aggalacang, Nogarata). Usually in a game, a kind of mussel shells are used as seed and if no, sometimes used also seeds of plants.

Supercilious game carried by two people. In their game board using a board called papan congklak with number of holes are 98 (14 x 7) and the seeds called biji congkak or buah congkak. Generally papan congklak made of wood or plastic, while the seeds are made of shells, seeds, stones, marbles or plastic (Figure 5.10). On board there are 16 holes which consists of 14 small holes that face each other and the two big holes on both sides. Every 7 small hole in the side of the player and a big hole in his right side is regarded as belonging to the player.

At the beginning of the game each little hole filled with seven seeds. Two players face to face, one who can pick holes start to be captured and put one into the hole on the right and so on (Figure 5.11). When the seeds out in a small hole that contains the seeds of another, players can take the seeds and continue filling, when discharged at his big hole then the player can continue by selecting a small hole in its side. When discharged in a small hole in its side, the players stop and take whole grains on opposite sides. But when stopped at an empty hole on the opposing side, the players stopped and did not get anything. The game is considered complete when there is no longer seeds that can be taken (whole seeds are placed in a large hole both players). The winner is who gets the highest seed.

While playing congklak many positive things that we can adopt. The use of wooden planks and seeds to play congklak indicates the utilization of natural resources around us as a means of games, which is consistent with the current echoed by many to be the "back to nature". With congklak, also train the precision and strategic to win this game. Another positive value is the value of honesty. While playing congklak we are accustomed to always be honest in carrying seeds in our hands.

Of a whole series of activities undertaken, turned out the participants were very enthusiastic in following each session given game. They feel that the games were presented very fun and challenging and far from being boring.

At the time, it also discusses aspects of the game that is the value of culture, philosophy, history, applications, benefits, and role. Lots of discussion arose about these aspects. In terms of cultural values proved that games archipelago has a high cultural value for many in the native language of each region both from the instructions given to songs that used to accompany the game, also the name of the game as well has given a hallmark of regionalism itself. Concerns and the desire to preserve the traditional game is built among the participants.

From the aspect of philosophy is found that the traditional game contains the basic philosophy of the Indonesian state which can be used as guidance in order to be individuals who are cultured. In terms of the history the game of archipelago took a big part in recording the history of development in Indonesia. Applications that do show that this game is aplicable to do in various places, situations, and the appropriate conditions, with a simple adjustment but still have high value and benefits.

As for the implications of the results of this study are as follows:

a. Success in conducting outing activity is influenced by the selection of the place and the material well. In determining the selection of the place and the materials of these things that the value of culture, philosophy, benefits, history, applications, and roles must be considered properly,

b. For the organizer of activities, need to pay attention to the capacity of the venue owned, pay attention to a good circuit for the smooth operation and attention to comfort for the participants so that a given message can be delivered.

c. As an Outing Planner in addition to pay attention to things related to the choice of the place is to learn about the characteristics of the participants, crowd management, event management, as well as everything related to the activities to be held.

\section{CONCLUSION}

It is a reality that the difficulty to play traditional games is not only they have to compete with the gadget as part of modern lifestyle, but there is no longer wide space for children to play outside the house. Moreover in Jakarta, nearly no wide space in each RT since every meter is used for home. This condition makes the traditional games is impossible to be played surrounding the house.

The philosophy contained in each games contributes to the development of the positive value for young generation and certainly will improve the quality of human resources. 
The traditional games contains many values. The value for mentality purpose is: help children to communicate their feeling effectively in natural way, to reduce anxiety, increase self-control and concentration exercises. The games procedures gives opportunity to children to move which make the children become relax in order to reduce anxiety. In some games, there are some moves that need full concentration such as Cublak Cublak Suweng so the children is learning how to concentrate. Self-control reflects on movement that needs control and calmness such as in Galasin. Problem solving reflects on how the children to create a strategy to win the games on Tak Benteng and Congklak; also how to distract the opponent in order to help our team pass the opponent on Galasin, and how to solve the conflict with team member.

The diversity of traditional culture must be preserved as cultural heritage since Indonesia has thousands of local cultural heritage. When other nation has only few of cultural heritage and they preserve it for their identity, then it is naïve if Indonesia has so many heritage but not eager to preserve the culture. Reconstruction of traditional games needs to be done in order the games is applicable to be played and the participant is easy to understand the value of each games. If the traditional games is introduced and played often, so more children know and understand the traditional games and the values. Automatically the preservation of traditional games will be sustain.

\section{REFERENCE}

Baskerville,L.R. "Investigating Information System with Action Research." Association for Information Systems, Atlanta, 1999.

Bishop, J.C. \& Curtis, M. Permainan Anak-anak Zaman Sekarang. Editor: Yovita Hadiwati. PT. Grasindo, Jakarta, 2005.
Borg \& Gall. Educational Research: an Introduction. Longman, Inc. New York, 2003

Danandjaja, J. "Foklor Indonesia: Ilmu Gossip, Dongeng, dan lain-lain.” PT.Grafitipers, Jakarta, 1986.

Davison, R. M., Martinsons, M. G., Kock N. "Principles of Canonical Action Research". Information Systems Journal, 2004.

Davison, G. dan C Mc Conville. A Heritage Handbook. St. Leonard, NSW: Allen \& Unwin, 1991.

DeBord, K. \& Amann, N. "Benefits of play in children: Age SpecificInterventions." Di akses pada 20 October 2013:

ttp://www.ces.ncsu.edu/depts./fcs/human/disas4.html

Dharmamulya, dkk. "Permainan Tradisional Jawa." Kepel Press, Yogyakarta, 2004.

Galla, A. "Guidebook for the Participation of Young People in Heritage." Conservation, Hall and Jones Advertising, Brisbane, 2001.

Hadiwinoto, S. "Beberapa Aspek Pelestarian Warisan Budaya”. Makalah Seminar Pelestarian dan Pengembangan Masjid Agung Demak, Demak, 2002.

Iswinarti. "Nilai-nilai Terapiutik Permainan Tradisional Engklek Pada Anak Usia SekolahDasar." Fakultas Psikologi Universitas Muhammadiyah, Malang, 2010

Madya, S. "Teori dan Praktik Penelitian Tindakan (Action Research)" Alfabeta, Bandung, 2006.

Sugiyono. "Metode Penelitian Kuantitatif, Kualitatif dan Research and Development." Alfabeta, Jakarta, 2008.

Sujadi. "Metodologi Penelitian Pendidikan." Jakarta. Rineka Cipta, 2002. 